antibody technique are equally naive: "...If the fluid portion of blood plasma is allowed to clot (fibrinogen precipitates out), or a relatively stable serum remains. This is made up of two protein fractions: albumin and globulin. The globulins consist of two alpha globulins, one beta globulin and one gamma globulin. ..." The author seems to have included these comments as a matter of policy without giving them much thought; her real interest appears to be in the methods themselves and it is easy to believe that she has had personal experience of most of them.

N. R. LING

Norman WitLIamson

\section{TEACHING PLANT PATHOLOGY}

Sourcebook of Laboratory Exercises in Plant Pathology (Sourcebook Committee of the American Phytopathological Society.) Pp. xxvii +388 . (San Francisco and London: W. H. Freeman and Company, 1967.) $68 s$.

The material in this book has been assembled in its present form by members of the American Phytopathological Society with the intention of encouraging a more experimental approach to the teaching of plant pathology.

The method chosen to achieve this aim has been to set down in detail a series of laboratory exercises in the hope that individual teachers may find at least some of the ideas pertinent to their particular courses.

The experiments cover all the major activities of the fungi, bacteria, viruses and nematodes in relation to plant pathology, while the standard of the exercises ranges from the straightforward isolation of fungi from the soil through to advanced research procedures only suitable for demonstrations. Some of the experiments will no doubt make interesting and worthwhile additions to specialist courses in this subject, and the descriptions of the techniques employed are, on the whole, lucid and informative. The very clarity of the text, however, is sometimes deceptive and many of the apparently "simple" exercises may well prove more difficult than indicated when executed by students not too familiar with the handling of micro-organisms. This possible drawback is enhanced by the fact that no real indication is given as to how skilled an experimenter needs to be in order to obtain the suggested results, and because many of the techniques are intended as innovations to general laboratory work, this lack of guidance may well lead to some disillusionment among those tempted to abandon familiar pathways.

The overall approach adopted in this book is, in many ways, rather disappointing, for the editors seem to have ignored the basic problem that they set out to solve, namely, "how the descriptive and taxonomic approach to the teaching of plant pathology may be integrated with the more dynamic aspects of the science". Thus, in compiling these exercises, those involved seem to have been thinking solely in terms of what should theoretically be included in a plant pathology course in ideal conditions, rather than concentrating on how the basic facets of the subject could be brought to life. For this reason it seems doubtful whether this book will go very far towards achieving its aims, whereas had the committee responsible for its production been content to influence a smaller audience, with the emphasis on enlivening and expanding the type of experiments suited to a particular group, then the book would probably have more impact. As it stands, with an apparent potential readership from high school children through to postgraduate research workers, it has simply become a collection of experimental techniques, and a potentially exciting project appears to have completely lost steerage through a failure to adhere to better defined parameters.
R. K. Robinson

\section{INSIDE PLANTS}

\section{Plant Anatomy}

By A. Fahn. Translated from the Hebrew by Sybil Broido-Altman. Pp. viii +534. (Oxford, London and New York: Pergamon Press, Ltd., 1967.) 758. net.

This book by the professor of botany at the Hebrew University of Jerusalem is an English translation of the Hebrew edition. It is intended as a general and comprehensive introduction to plant anatomy and as such it is conventional in plan. The book begins with a consideration of the cell; has chapters on meristems, tissues, the primary and the secondary plant body, and concludes with three chapters on reproductive organs.

Any text book on plant anatomy must deal with a vast quantity of facts and, perhaps inevitably, mistakes will occur. This book is no exception. For example, parenchyma is not always composed of living cells as is implied on page 73 , neither is all collenchyma formed in the way described on page 80 . The statement on page 273 "that in woody ... [plants] . . . the primary tissues of the stem and root exist for a relatively short period before they become destroyed or obliterated by the development of the secondary vascular tissue ..." is not only wrong and misleading but suggests some misunderstanding of the process of secondary thickening.

On page 292 it is stated that resin ducts occur in the secondary xylem of Abies and Cedrus, two genera in which resin ducts do not normally occur although occasionally traumatic ducts may be found, more particularly in Cedrus, and it is these abnormal ducts which are illustrated in Fig. 128.2.

There is in many places a lack of precision in the writing and in many instances statements on the same topic in different places are not consistent; for example, xylem as defined on page 102 and subsequent deseriptions of this tissue. There are other examples and it may be that these are, at least in part, the results of the problems of translation.

An undergraduate student using this book will learn many facts about plant anatomy, but I doubt whether such a student will obtain an integrated picture of the structure of a living plant. Perhaps the author has tried to include too many facts so that it has become difficult. to see the wood for the trees.

The book is copiously illustrated, but the illustrations vary in quality. The line diagrams are generally clear but the same cannot be said for all the micrographs. The student is likely to find Fig. 117 or Fig. 120.2 difficult to interpret.

Most of the genera, if not all the species, of plants referred to will be familiar to students in this country. The book has a glossary, and is provided with both an author and a subject index.

D. J. B. WhITE

\section{EXPERIMENTAL ANIMAL ECOLOGY}

\section{Introduction to Experimental Ecology}

By T. Lewis and L. R. Taylor. Pp. xi+401. (London: Academic Press, Inc. (London), Ltd.; Now York: Academic Press, Inc., 1967.) 37s. 6d.; $\$ 6.50$.

As a university teacher who is continually faced with first year students completely lacking any previous practical ecological experience at the school level, it was with considerable pleasure that I read Introduction to Experimental Ecology.

It is obvious a considerable amount of work and careful selection of material has gone into the preparation of this book. The exercises are chosen from a wide range of habitats, which makes the book equally valuable to schools situated in towns as well as the more fortunate rural ones. The statistical treatment of the data has been 